\title{
Umbilical Accord and Symbiosis between Man and the Environment: A Stylistic Analysis of Selected Poems of Joe Ushie's Hill Songs and Unimna Angrey's Drought (Ubuang)
}

\author{
Godwin Oko Ushie \\ Department English and Literary Studies, University of Calabar, Calabar, Nigeria \\ Idaevbor Bello \\ Department of English, University of Benin, Benin City, Nigeria
}

\begin{abstract}
This paper analyses selected poems in the poetry collection of Joe Ushie entitled Hill Songs and those of Unimna Angrey's collection entitled Drought (Ubuang). It is an investigation of the linguistic choices that the selected writers have made in order to establish their connections with their environment and the representation of the effects of the negative and unfavourable conduct and destructive activities of man on it (the environment). The paper uses a conflation of three theories- ecofeminism, modification in grammar and conceptual theory of metaphor. In this respect, focus is mainly on the use of lexical items, verses, the imagery and certain literary devices, such as metaphor and simile, that the poets deploy in their works to establish that connection and the attack that the environment, which man is inextricably a part of, has undergone in man's quest for development. The aim is to draw attention to the poetic discourse on the effects of the man's interactions with the environment as expressed by these new poets. The paper concludes that the poets' concern for, and conviction about the symbiosis between man and the environment have constrained the deployment of anthropomorphic and anthropocentric idiom and the style of their poetry.
\end{abstract}

Index Terms - man, anthropomorphic and anthropocentric idiom and style

\section{INTRODUCTION}

The concern for the environment, in view of the inextricable link with, and the mutual interdependence of, man and the environment has found expression in a number of literary works, poetry, inclusive. Poets particularly have a unique way of semiotizing their sensibilities, demonstrating their concerns and capturing the symbiosis between them and the environment. And when they witness a devastation of the ecosystem, they do not fail to hide their feelings and point out the effects on the world. Andrew Bennett and Nicholas Royle (1995) have observed that:

twenty-first century global capitalism is currently facing the possibility that within the lifetime of many of us living today, our rapacious, land-grabbing, polluting rage for road and air-travel, consumables and other material possessions will lead inexorably, unstoppably to the effective destruction of more or less all life on the planet (p.141).

This position might sound alarmist but it is a timely call to us all that we must begin to reflect on our actions in relation to how we view and manage the environment that we live in, and that the consequences that await us in the not too distant future if we continue to selfishly exploit and destroy the environment, are grave. If the ecology is viewed purely from anthropocentric lenses, that from the belief that the environment exists only to serve man and so should be exploited as such without regard to how man should preserve it and sustain their interdependence, not only nature, but man will ultimately suffer.

\section{LITERATURE REVIEW}

Joe Ushie's poetry has received quite some critical attention for his concern with the problems of poor leadership, corruption, despoliation of the environment, and the like. For instance, Bassey Ude Bassey (2008) in his study he entitles "The Hills and the Vales: Images of Leadership in the Poetry of Joe Ushie," discusses the social contents of Hill Songs. He writes "... the poet consistently refers to the hills as a place of refuge, a symbol of attainment, and the source of life" (p.32). We agree with this assertion and posit that it is the attempt to denude the hills of these positive qualities through the negative actions of man that is one of the concerns of the poet in this collection. And this is the preoccupation in the Angrey collection too.

Romanus Aboh (2010), on the other hand, discusses the poetry of Ushie from the perspective of the poet's usage of certain linguistic items from his mother tongue and other sources in his creative enterprise. In "Lexical Borrowing and the Construction of Identity and Politics in Ushie's Poetry," the title of the paper under reference, Aboh asserts that 
Ushie's poetry “... shows a pattern of great incorporation of indigenous vocabulary as well as grammatical forms in English" (4). In yet another study that he entitles "Modality as a Discourse Strategy in New Nigerian Poetry," Aboh again tells us that in Ushie's consideration, "poetry is a potent form of rebuke and purification. He, therefore, (sic) draws a distinction between those who use poetry to support the excesses of government and those who use poetry to reflect and refract the ills in society" (8). But he does not show how he uses these to comment on the state of the environment in the poetry. In other words, Aboh, in his studies of Ushie's poetry, does not pay attention to his relationship to his environment and how he uses his language to reflect that bond that exists between the writer and that environment.

Saeedat Bolajoko Aliyu (2013) examines the aesthetics of place in Hill Songs from an Ecocritical perspective and observes that the poet, Ushie, uses place as a discursive tool which enables him to catalogue the functionality, spirituality and mysticism of nature while engaging in a political venture of mediating for those whose very existence is tied to the preservation and the humane exploration of its components Hence, Ushie's deployment of the aesthetic of 'Place' is dual in function: as a framework for an exploration into how contemporary poets perceive and utilize nature in their creative ventures; and as a political tool to champion the quest for proper handling of the environment and the people affected by it in the face of capitalist and industrial demands for resources. (p. 145)

We share Aliyu's observation especially the assertion that Ushie uses his poetry to intervene in the lives of the common people, the deprived, in their struggle for space and survival in the Nigerian landscape. Ushie's attempts at drawing attention to the devastation that the environment has endured in the quest to probe for the riches that lie beneath is also at the heart of the poetry.

Godwin Ushie and Koton Ofem (2013) in linking the nexus between the social concerns and style in some poems of Unimna Angrey show that the social situation upon which the poems are based, to wit, poverty in the midst of plenty and environmental degradation provides the metaphor for the language of the poems and hence the style. They read a political representation of the agents of poverty as predator birds that not only destroy the ecosystem, but also leave the pastoral people who depend on the ecosystem in "tattered penury". These agents are semiotized as politically powerful people from the north who swoop on the ecosystem.

The next subsection critically examine the two collections of the two poets under study in this essay to see how they create that connection between the poet personae and the natural environment around them through the intermediary of lexical choices.

\section{THEORETICAL FRAMEWORK}

This paper benefits from a synthesis of Ecofeminism, Modification and the Conceptual Theory of Metaphor. Ecofeminism essentially interconnects the oppression of women and that of nature. It espouses the view that "[d]iscrimination and oppression based on gender, race and class are directly related to the exploitation and destruction of the environment" and that they are wrought by patriarchy (Metz, 2008). While some ecofeminist critics view the link between the woman and nature in positive, empowerment lenses, others view it negatively as degrading and as having been imposed by patriarchy. The import, and hence the value, of this theory, is in the analogy that as male sees the female as a sexual object to be exploited, so is the environment looked upon as an object to be exploited. Anthropocentrism (the view that the environment is meant for man to dominate, exploit and even destroy in the process) therefore, is coterminous with sexual exploitation of the female by the male.

Modification is the grammatical tie that exists, for example, between an adjective and its noun, or a verb and its adverb" (Rogers, 2000). Sometimes an adjective may modify a whole phrase or clause; a clause may modify another clause, a phrase or even a word (in which case it is labelled a "rankshifted clause". Sometimes a nominal can be used to modify another nominal. In modification of nominal, a modifier may come before or after the head, that is the nominal it is modifying. When an epithet (an adjective) or even a noun that modifies another comes before the head, it is called a (pre) modifier. And when it comes after the head, it is called a qualifier in Systemic Functional Grammar or a postmodifier in Transformational Generative Grammar.

Essentially, modification of nominal generally, whether by adjectives or adjectival structures (rankshifted structures) supplies additional information about the head or it specifies/ limits the nominal. This means that modification is an asset in description/ descriptive focus. It is this quality that makes modification fit into the theoretical framework of this paper.

A metaphor transfers the quality (ies) of one object to another directly and hence makes comparison in the process of description very effective. Goatly (1977) asserts that "a metaphor occurs when a unit of discourse is used to refer to an object, concept, process, quality, relationship or world to which it does not conventionally refer or colligates with a unit(s)with which it does not conventionally colligate...."(p.105).

In cognitive linguistics, metaphor consists of a source language and target language and a set of mappings between the source and target. Metaphor is an understanding of one conceptual domain (the source) as another domain (the target), hence "the conceptual domain of A is the conceptual domain of B" (Kovecses2010 quoted in Krisnawati, 2014).

The usefulness, therefore, of this triadic theoretical framework is that the modification/ qualification of the environment in the poems symbolically and metaphorically describes the environment as woman that is exposed to exploitation and abuse, the environment and the woman being coterminous. 


\section{DISCUSSION}

As pointed out earlier, the objective in this study is to assess the collections of the two poets under study with a view to establishing their stylistic choices which reveal the connections of their poet personae to their environments. Both writers come from places that have the same geographical features of hills and valleys; environments that are in the montane vegetation belt within the tropical forest region of Nigeria, specifically in Cross River State; for this reason their choices of language to express the ambience of that environment portray an uncommon bond between man and his environment in their poetry.

In "Hill song" (pp.9-12), the first poem in the collection and which also gives the collection its title, Ushie represents his affinity with his environment through his choice of certain linguistic terms, especially his choice of modifiers. In the very first stanza of the poem, the persona tells us of his closeness to the hills of his birth thus:

O hills of my birth/ My post-natal womb/Silent shields whose gallantry

Beats time, beats clime (p.9) (Emphasis (italics) here and subsequently are ours).

In the extract, the use of modifiers establishes the link the persona has with the hills of his birth; the relationship that is established in the first line is personal as shown by the possessive (pronoun) modifier 'my.' The modifiers, whether as epithets or as qualifiers, in these poems become a code for capturing the symbiosis between the poet persona and the environment. The hills have a personal link with the persona as against a general link; he has appropriated the resources of the communal to a personal end. The hill is foregrounded in the poem by its repeated use in the opening line of each of the first three stanzas of the poem. This situates for the reader the fact that the persona is nostalgic about the hills and holds them dear to his heart.

The fact that the poet treasures his environment, the "hills of [his] birth, and inveighs them with much love and admiration is further established by the pre-modifiers in lines 2 and 3 - 'my post-natal womb' and 'silent shields', all of which are metaphoric. The persona enjoys the serenity of the hills of "[his] birth" as much as the unborn child enjoys the comfort of the womb of its mother; that is why the hills are equally "silent shields" shields being indicative of this their protective nature. The hills at once have motherly and military protection for the persona. Hence, the anthropomorphic terms here amply establish an uncommon bond between the persona and his environment as represented in the hills of his birth.

This argument of the hills as protective shields runs through to the eleventh stanza of the poem. All through the poem, the persona addresses the hills as if they have life; he personalizes them through the use of apostrophe. For him, the hills have become human, even a god with their brooding presence. In each of these first eleven stanzas, this direct address to the hills comes through -

"O hills of my birth" - lines 1, 5 and 9; "Your ridges like forgotten garden" - line 12;

"Your crown of rocks worn" - line 15, etc.

This style of direct address or the use of apostrophe in these examples and in the opening lines of each of the next eight stanzas of the first eleven stanzas affirms the positive qualities of the hills and the surrounding environment; and it makes it more harrowing when we are confronted with the negation of these qualities beginning from stanza twelve when man's actions begin to take their toll on this environment with its protective garb. The modifiers in these stanzas which have positive connotations are used about thirteen times to underscore the value the hills have for the persona and not just the people but also for nature itself, hence the symbiotic interdependence. As the persona tells us in stanzas five to seven, man, animal, and plants alike are nurtured by the hills and their resources:

Your crown of rocks worn berets in whose womb/The rodents dwell

$\mathrm{O}$ the sand-filtered springs/ Leaping from your groins/ To nurture man, beast and tree

Twilight and you roost in silence/ Tree and earth passed into/A garment of night fondled by wind

In this extract, the rocks that are a part of the hills' environment provide abode for the rodents. We cannot miss the military image through the use of simile in the first stanza of the extract; it establishes once more the protective force of the hills. The rocks are like a beret, a military symbol, in whose bowel the rodents find a home.

The modifier in the second stanza of the extract which describes the springs is quite apt as it captures the quality of the springs. The compound form of the modifier, "sand-filtered," is striking in itself; it is made up of a nominal and a verbal adjective. It shows the purity of the water in its natural state as it is unaffected by man's action on the hills. The water of the springs has both healing and generative properties hence it is able to nurture not just man, but also beast and trees. Man in the natural state of the hills lives in harmony with nature because he is a part of the environment. It is because of this that at night, "trees and earth" are united in the protective covering that the hills provide which he metaphorically refers to as "a garment."

The second part of the poem does not convey that positivist outlook that we encounter in the first part chiefly because of man's negative actions on the environment and its ecology. The poet marks this separation of the poem into two parts by his choice of linguistic markers, through juxtaposition, and not by physical separation. In stanza 12, he tells us: "But by axe and flame / You stand undressed, nude / Like an anthill at the market place" (10). The modifiers in this extract, "undressed" and "nude," are post-posed; they are the complements of the subject in the second line of the extract, "You," which has the same referent as the "... hills of my birth" in line one. This undressing and nakedness of the hills is as a result of man's action - deforestation. This action has made bare the hills which, as a result have lost their protective covering for man and nature. The hills assume the image of a helpless woman who is forcefully stripped 
"naked," "undressed" and violated. The metaphor and the simile are unmistakable; they show that like the anthill, and in this case the one in a market place, there is no single vegetation left of the hills.

This image of helplessness runs through to the end of the poem, the image of man's predatory nature and greed that have robbed the hills of their greenery and life. In an agonizing voice, the persona laments the deplorable state the hills are now in which is as a result "greed-fanned flame," "greed-clad axe," and so result in "greed-brewed death," all compound modifiers which pre-modify the nouns flame, axe, and death to show that man's greed has no limit. The persona resorts to the use of repetition to underscore the state of the hills in order to make their state stick in the reader's mind. "[T]he widow," "the orphan," and "the weak," in that order are left helpless by the actions of those who have denied the hills of their "bloom."

Conceptually analysed, the image of the environment couched in metaphoric terms is clear in the following lexical items/structures:

Source: ECOLOGY

...my birth

...postnatal womb

...wombs rodents dwell in

...your groin

You stand undressed, nude

umbilical accord

\section{Target: MOTHERHOOD/WOMANHOOD}

Mother

Mother

Mother

Woman

Woman violated

inextricable filial bond

Another image captured in the metaphors and modification is that of military men giving protection to humans, the flora and fauna.

Source: ECOLOGY

...crown of rocks worn berets

Silent shields whose gallantry

A garment of night fondled

\author{
Target: MILITARY/ SECURITY \\ military presence \\ protective cover \\ protective covering
}

This same bond is established in the poem, "Back to Kugbudu" (pp.28-29), wherein the poet laments the deprivation and the neglect of both the environment and the people by those who are "Cushioned in sleek cars which whiz / Past wind-filled shirts housing / Abstracted pedestrians" (p.28). The modifiers "sleek," "wind-filled," and "abstracted" show a difference in the life styles of the privileged and the deprived. "Cushioned" and "sleek" convey images of comfort, relaxation, and contentment, whereas "wind-filled" and "abstracted" convey the opposite especially when we remember that these refer to pedestrians who are open to weather elements and deep in thought to the extent they are oblivious of what is happening around them as "Each [is] with his Nile of woes," hence they are abstracted.

In this extract, the poet deploys a total of twenty nine modifiers to describe the people and their environment. All these modifiers communicate something negative except "... the over-fed [who are] Cushioned in sleek cars". For instance, "erosion-serrated road," "famine-pelted mango trees," "A forgotten book, dust-browned and pale," "scaly streets," "Helpless reapers of crown-grown penury," etc communicate a sense of abandonment, total deprivation, and complete neglect of the common people and the country side. The people and their community and their daily struggles are "re-membered only during ballot season," when promises are distributed in quantum unhindered "At that sweetpoisonous tongue of the / crowd-prone chameleon" (p.29). The modifiers here convey that negative trait we have referred to earlier as what the tongue, a synecdoche for the politician, says has the potential to destroy; that is why it is "sweet-poisonous," an oxymoronic expression deployed by the deceptive politician ("chameleon") to momentarily excite the crowd who live through an instance of willing suspension of disbelief.

In "From hill to valley" (pp.33-35), the last poem from Ushie's collection that is examined in this study, the same bond between persona and the environment is recreated and the decimation of that ecological haven is again lamented. The poem opens in the form of an oral narrative, which is a stylistic marker for story telling; the story of the hills: "Once upon a hill / trees stood as Goliaths / dressed in resplendent ferns" (p.33). The modifier, "resplendent," which qualifies the noun "fern" at once situates for us the lushness of the hills at a point in time past and the nostalgia that invokes in the persona. The opening line prepares us for the despoliation that we will encounter later as we read the poem further. The trees were at some point like Goliaths. This Biblical image calls to mind the huge Philistine that David had to contend with in order to rescue Israel. These Goliath-like trees do not stand the test of time as they are soon laid bare by man's greed.

The beauty that the persona presents to the readers in the first eleven stanzas of the poem contrasts sharply with the gloom in stanza thirteen; stanza twelve presages that movement from bloom to gloom; it marks the turning point of the beauty of the first part with the gloom of the second. As we have observed, the modifiers in this first part of the poem connote positive images. We have as examples the following for illustration:

i "resplendent ferns" - line 3

ii "... the iroko's / expansive empire" - lines 4 and 5

iii "... bougainvillea / brandishing / her multi-racial flowers" - lines 13-15

iv "its milky clouds of wool / sailed leisurely over the valleys / on a sea of steel-muscled wind" - lines 24-26, etc. 
The extracts present vivid images of beauty, solidity, aesthetics, allurement and sturdiness; all of these combine to make the hills an abode of serenity that was once an inviting spectacle to any keen observer. But now the reverse is the case as the persona bemoans the decay and destruction that has taken place on the hills; what is now in place is that:

Every dry season, /undressed rocks like skeletons/lay open on crowns of the hills in grove's homesteads/tending orphan shrubs,/ nursing wilting rills (p.35)

This is happening because the iroko, mahogany, and silk cotton trees that used to provide protective coverings for man, animal, and these shrubs and rills have all either been cut down or burnt through the actions and greed of man. In this second part of the poem we encounter such modifiers as:

"black cloud" - line 45; "undressed rocks like skeletons" - line 53; "orphan shrubs" - line 56; "grave-faced valleys" - line 61; "sterile spear grass" - line 63, and many others.

These are linguistic terms / markers that convey negative sentiment as they portray the present condition of the hills as having been stripped of all that represented the beauty and solidity that was its armour in times past. The poet's style of juxtaposition is to establish the agonizing state of things in their present condition as compared to what was that he feels nostalgia for.

In Drought, Angrey, like Ushie, connects us with the landscape of his ancestral home of Kigbor-Ukpe, the flora and the fauna and equally establishes a relationship that is deep and pervading all through the poems in the collection. The first poem in the collection which is titled "The first call" (1) establishes that connection. The poem opens with the remembrance of the first urging to return home to the hills, the Ukpe hills the persona's homestead; a call which he headed. The poem is written in quatrains of free verse, and it contains four stanzas with the first stanza opening with: "I first heard your strident calls/ at the banks of the River Wouri/ they pierced through the walls of my Bessèkè marshes home"

The persistence of the call is underscored in the first line because it is "strident," and it is therefore inevitable that he has to answer it. We are kept in suspense as to who the caller is until the second line of the fourth and last stanzas of the poem when the persona lets us in: "I have come here to stay / my mother-like Ukpe hills." He personalizes the hills because of his love for them and the metaphoric reference to them as mother further reinforces that connection. According to him, the hills offer a "cool embrace" "and nestle me in your wide / arms like a mother her baby." The phrase "wide arms" indicates that the hills are welcoming to all the children of the land who answer the call to return home and have the resources to cater for all like the generous mother that they are. The bond as in Ushie is deep as the hills are assigned motherly role over the people.

The persona answered the call more than two decades before he is recounting the experience to us. He has never had any regret since then. After he hears the "strident call," he "... traversed rivers and streams / vales, mo[u]nts (sic) and meandering hills / along the bumpy Kumba-Mamfe road." He is delighted to recall that strenuous journey homeward to pay obeisance to the "mother-like Ukpe hills;" to answer the call of his progenitors who, as we are later to find, dwell in these hills.

"Ejimashor," a poem which the poet dedicates to his kinsfolk in Kigbor - Ukpe, is divided into thirteen sections of three quatrain stanzas each thus making a total of one hundred and fifty six (156) lines. In these lines, the persona explores the ever present river, Ejimashor, which protects, heals, cuddles, fertilizes, and feeds the children of Kigbor now as in the past. Ejimashor is "bountiful stream" and "purveyor of hope and life" for the persona and his kinsmen of Kigbor. The persona tells us of longing from the beginning to have a rendezvous with the river

I had sought to see your face / in the pristine hours of my youth / I had not yet felt your presence but you sat close to my mind.

It is the bond, that connection that the persona shares with Ejimashor that makes him both an admirer of and a supplicant to the "bountiful stream." The persona style here is to address and celebrate the stream like an adoring child would a parent who had shown love and care to the child. The persona underscores yet again the power of Ejimashor to provide for the people when he tells us:

I have come to you/ Kind stream of all times/ I keep admiring you as you glide

Your snaky way down the hills / down to our most fertile soils/ into which you incessantly run

in your unfettered journey/from the most cherished Ukpe monts (sic). We see here that the stream is "kind," "snaky" in its movement, "fertile," and "unfettered." These adjectival modifiers clearly illustrate the stream's value to the people who inhabit the hills; it does not discriminate in its fertilization of the land for the people to gain maximally from their toil on the soil.

The "unfettered journey" of the Ejimashor stream contrasts sharply with the Abe River of Ushie. In Ushie's poem we are told that: "Old now, the Abe River goes / Wearily bearing bundles of woes" (p.29). This invokes pain and anguish, whereas in Ejimashor the tone is pacy, expectant, and excited.

Angrey in this poem makes use of these pre-modifiers about sixty five times and post-modifiers a lot fewer times, and all of these are positive. This is to show that all through he celebrates the natural state of the hills and the beauty and healing qualities of Ejimashor. He is not so much preoccupied with the destruction that takes place around him like Ushie vividly does in Hill Songs. His is both celebrative and supplicatory, as shown in section VI (p.20) of the poem. The persona tells us: I have now kissed your face/for three and twenty years/your bountiful flow of blessings/ does compensate us for our work 
That relationship of kinship is again established in this line through linguistic choices; in the manner the persona addresses what we may rightly term the stream of life. The mother -child relationship established earlier continues here as shown by the verb, "kissed;" and this has been on "for three and twenty years." And because of their loyalty and dedication to Ejimashor, its "bountiful flow of blessings does compensate [them] for [their] work." Both the stream and the inhabitants, the community benefits from each side; while the people pay their respect to the stream, it in turn blesses the work of the hands of members of the community. This position is further reinforced in the last two stanzas of the section when the persona tells us that:

Your ceaseless flow down/ to the young dying palm trees/ of the luscious Ikem-Akpe/ is a banner of our common bliss/ You're the thread of unity/ that binds Kigbor children/ they are to the fertile soil /bound by your bountiful face

It is clear from the modifiers deployed in this extract that the stream, Ejimashor, is regenerative, productive, unifies and forever present to direct the destiny of the of the people of Kigbor towards their desired destiny. It binds and unifies the people together in their journey through life. These images of the stream run through the other sections of the poem; at one point it is a "good mother" with "daughters brave," and at other times it is a "soothing balm to / wipe away sour tears / of labour pains;",

In the last section of the poem, section XIII (27), the persona changes the celebrative tone of the earlier sections of the poem; there is now a connection between the "ceaseless flow" of the stream "down its inevitable course" with the persona's "... final journey / down the rugged road of life." However, even though he has been made aware of this inevitable journey "from them under these trees laid," this which is an obvious reference to his forebears, the persona is "not in a hurry to tread it" yet. The constancy of the flow of the stream, since it is "ceaseless," is a reminder to the inhabitants that their individual lives are on immutable ebb to that final end to which all human lives are subject. This style of connecting the steady flow of the stream to the gradual but inevitable ebbing away of human life has the force of oral or folklore authority. The stream Ejimashor plays multi-faceted roles in the lives of the Kigbor people.

Ushie \& Ofem (2013) read a political undertone in the poem "Men from the North" in which the poverty agents are semiotized as predator birds that cause artificial poverty. It is ironic that the northerners who came "in tattered penury" (line 1) left with the juiciest fruits leaving the people "in tattered misery" (line16). The farming folk work the soil with their bare hands and reap the crops which they hardly enjoy because the northerners in great numbers come to "the Delta, like rapacious birds of prey," and pick the "juiciest fruits". The owners and tillers of the land are bereft of land, food and aquatic life as "the ecosystem is so devastated" (lines23-15, p.8). The Niger Delta indigenes suffer this devastation of the ecosystem in the forms of polluted water that destroys marine life, blighted flora and fauna and degraded land. In this poem man's relationship with the ecosystem is that of destructive pests that unabashedly and selfishly exploits and destroys the environment. Man is likened to "rapacious birds of prey" (line11, p.7) that suck the "juiciest fruits". The effect is bizarre: "the owners of the land" are left /without land, without food and fish/ the ecosystem is so devastated/ the men are left in tattered misery $(1114-16, \mathrm{p} .8)$.

\section{CONCLUSION}

In this paper we have attempted a study of the place of mainly the use of modifiers and conceptual metaphors to establish the connection between Joe Ushie and Unimna Angrey in their poetry. We demonstrate that their use of lexical items which is highly anthropomorphic shows their abiding commitment and attachment to the hills, a topographic feature of their ancestral homes. Their use, also of modification becomes a code for semiotizing and foregrounding the symbiosis between man and the ecosystem. We showed that whereas Ushie is concerned with the effect that man's action has wrought on the hills, Angrey on the other hand is mainly concerned with the protective cover that the hills, with its flora and fauna, offer, except in "Men from the North" in which the ecosystem is devastated by man. The analysis also shows that the environment, like the woman is seen purely from anthropocentric perspective, the perspective of an object to be exploited without regard to sustainability in use. It is couched in the image of a woman good only for use and not for preservation

Beyond the use of modifiers to establish that "umbilical accord" and the symbiotic relationship between the poets and their homelands, the poets make use of other stylistic markers such as inversion, sound features such as alliteration and others. Both poets also resort to their respective mother tongue to borrow certain linguistic items to add local flavour to their style.

\section{REFERENCES}

[1] Aboh, R. (2010). Lexical borrowing and the construction of identity and politics in Ushie's poetry. The Southeast Asian Journal of English Language Studies. 16: 1, pp 1-30. Print.

[2] Aboh, R. (2012). Modality as a discourse strategy in new Nigerian poetry. Journal of Nigeria Studies 1: 2, Fall, pp 1-18. Print.

[3] Aliyu, S. B. (2013). Aesthetics of place in contemporary Nigerian poetry: An ecocritical reading of Joe Ushie's hill songs. Journal of Literary Society of Nigeria, JLSN, Issue 5. 142-9.

[4] Angrey, U. (2006). Drought (Ubuang). Calabar: Optimist Press, Print.

[5] Bassey, B. U. (2008). The hills and the vales: Images of leadership in the poetry of Joe Ushie. CALEL Vol 5, pp. 20-33. Print

[6] Bennet, A. \& N. Royle. (1995). An introduction to literature, criticism and theory. Harlow: Pearson, $4^{\text {th }}$ Ed, 2009. Print

[7] Goatly, A. (1997). The language of metaphors. London: Routledge. 
[8] Krisnawati, E. (2014). Metaphors in Indonesian soccer news. in Theory and Practice in Language Studies. Vol. 4.No.1 pp.2429.

[9] Metz, W. F. (2008). How ecofeminism works. http://science.howstuff.com/environmental/greenscience/ecofeminism.htm posted 03 February 2014, Accessed on 06 February 2014.

[10] Rogers, W. E. (2000). A simplified structural syntax. Available from World Wide Web eweb.furman.edu/wrogers/syntax/index.htm. Posted August 22, 2000, Accessed 06th February 2014.

[11] Ushie, J. (2004) Hill songs. Ibadan: Kraft Books, Ed. Print.

[12] Ushie, G. O. \& K. U. Ofem. (2013). The nexus between social concerns and style: A study of selected poems in Unimna Angrey's Drought (Ubuang). World Journal of English Language Vol.3 no. 2 pp. 44-51.

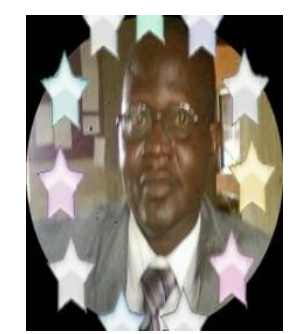

Godwin Oko Ushie was born on April 21, 1966 in Nyanya Ulim, Bekwarra, Cross River State. He holds a Bachelor of Arts (Education) English, a Master of Arts (morphology) and a Doctor of Philosophy (stylistics), obtained from the University of Calabar, Calabar, Nigeria. He has been teaching English courses at both undergraduate and graduate levels such as Discourse Analysis, Textlinguistics, Stylistics, Morphology, etc at the University of Calabar for sixteen years now.

$\mathrm{He}$ is currently on a Sabbatical Leave at the Federal University, Lafia, Nasarawa State. He has at least thirteen (13) research articles in reputable local and international journals such as "Dialectical relexicalization in Festus Iyayi's literary idiolect: Componential analysis approach." LWATI: A Journal of Contemporary Research, June 2011 pp.92-100; Descriptive focus as a semiotic marker in Festus Iyayi's Violence. Studies in Literature and Language Vol. 5, No. 3, 2012, pp. 36-39; "The nexus between social concerns and style: A study of selected poems in Unimna Angrey's Drought (Ubuang). "in World Journal of English Language Vol. 3, No. 2; 2013, pp.45-51, etc.

Dr. Ushie's research interests include Stylistics, Semiotics and Applied English Linguistics. He is a member of the Reading Association of Nigeria (RAN) and Association of Nigerian Authors (ANA).

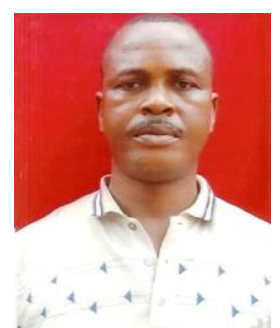

Idaevbor Bello was born on the $5^{\text {th }}$ of September, 1965 in Iyakpi, South Ibie, in the present Etsako West Local Government Area of Edo State. He holds the Bachelor of Arts (B. A.) and Master of Arts (M.A.) degrees which he obtained from the Department of English and Literature of the University of Benin in 1992 and 1997, respectively. He specializes in Literature. He has taught such courses as Medieval \& Renaissance Literature, Metaphysical Poetry, 17th Century Literature, Restoration $\& 18^{\text {th }}$ Century Literature, Romantic Poetry, Major Genres of African Oral Literature, Argumentative Composition, introductory courses in poetry, oral literature, and drama amongst others. He is currently a Doctoral student in the Department of English and Literary Studies, University of Calabar.

He has publications in local and international journals. Amongst these are "Sam Ukala: African Tradition in His Plays." Journal of Pan African Studies, JPAS, 6:5, (November 2013). 115-131, "Revolutionary Strategies: The Poetry of Odia Ofeimun." New Nigerian Poetry Journal. (2005), 85-100, and "Literary Research as an Ennobling Art." Nigerian Journal of Humanities 18 (2012), 82-93. His major area of research interest is the interpretation of literature from the Marxist and New Historicist theoretical perspectives. And he is a member of the Literary Society of Nigeria, LSN and the Nigeria English Study Association, NESA.

Mr. Bello has been involved in civil society work since his days as an undergraduate and has held positions in Campaign for Democracy, CD, and Committee for the Defence of Human Rights, CDHR, between 1994 and 2003. He has also been involved in labour activism at the level of the Academic Staff Union of Universities, ASUU, where he has served as Assistant Secretary and Secretary of the UNIBEN branch between 2002 and 2010. He has served, and has continued to serve, in different committees of the Union at the local (branch) and at the national levels at different times. He is married to Mrs. Toluwa Becky Bello and they have five children. 